\title{
The Cambridge Encyclopedia of Earth Sciences
}

\section{Edited by DAVID G. SMITH}

The Cambridge Encyclopedia of Earth Sciences is an authoritative high-level reference work covering the broad span of the Earth Sciences, and concentrating on those areas in which significant progress has recently been made. The scope embraces the formation of our planet, its past history, and present properties, rocks, minerals, and geophysical processes, through to extraterrestrial geology.

\&19.95 net

\section{The Stratigraphy of the British Isles Second Edition DOROTHY H. RAYNER}

This new edition of Dr Rayner's standard textbook on the stratigraphy and historical geology of the British Isles has been extensively revised to take into account fifteen years of further development since the first edition was published, and reflects present understanding of the role of plate tectonics in shaping the geology of an area.

Hard covers $£ 32.50$ net Paperback £12.50 net

\section{Earth's Pre-Pleistocene Glacial Record}

\section{Edited by M. J. HAMBREY and W. B. HARLAND}

This massive 1024 page book presents the results of the major international survey set up in 1977, the Pre-Pleistocene Tillite Project. This project has provided a reliable data base for studies of the sedimentology of glacial environments, palaeoclimatic patterns and palaeogeological reconstruction, time correlation of pre-Cambrian rocks, and processes that relate to climatic change and the origins of ice ages. This book will be invaluable to those doing research in these fields, and will remain the definitive survey for many years to come.

\&98.00 net

\section{Cambridge Earth Science Series}

\section{The Earth: Its Birth and Growth}

\section{MINORU OZIMA}

\section{Translated by J. F. WAKABAYASHI}

Professor Ozima's readable account of the evolution of our planet during 4.5 billion years emphasises Earth's early history - the accretion of the Earth from solar nebulae, the formation of the layered structure of the Earth, the evolution of the oceans and the movements of the crust-but also includes a discussion of current practical problems such as the disposal of radioactive waste.

Hard covers $\$ 10.50$ net Paperback \&3.95 net

\section{UNIVAMBRIT PRESS}


IGPC Project 58 Mid-Cretaceous Events

\title{
Aspects of Mid-Cretaceous Regional Geology
}

edited by R.A. Reyment and P. Bengtson

July/August. 1981, $x+328 p p .$, f30.00 (UK on/y) / \$72.00, 0.12.587040.X

The mid-Cretaceous has provoked considerable interest - so much so, that in 1974 the International Geological Correlation Programme established a special project devoted to the study of "Mid-Cretaceous Events".

Contents: Preface. K.-A. Tröger: German Democratic Republic. D.P. Naidin: The Russian Platform and the Crimea. Mikhail A. Pergamentt: Pacific regions of the USSR. P. Saint-Marc: Lebanon. R.A. Reyment: West Africa. R. Förster: Mozambique. R.A. Reyment: Colombia. Otto Renz: Venezuela. J. Ian Raine, lan G. Speden and C.P. Strong: New Zealand. Michael R.A. Thomson: Antarctica. Subject index. Index of fossil species.

Volumes 1, 2 and 3

\section{The Geology of Libya}

\author{
edited by M.J. Salem and M.T. Busrewil \\ July/August 1981 \\ Volume 1: xvi + 348pp., £20.00(UK only) / \$48.00, 0.12 .615501 .1 \\ Volume 2: $x i i+430 p$ p., f20.00(UK only) $/ \$ 48.00,0.12 .615502 . x$ \\ Volume 3: $x i i+338 p p .$, £20.00(UK only) $/ \$ 48.00$, 0.12 .615503 .8
}

The symposium of which these volumes are the record - held in Tripoli in Al-Fateh University, September 1978, was the second of its kind to be held on the subject. Since the first, in 1969, so many new data and ideas have come to the fore that it has become essential to be able to find in one place a complete survey of the decade's work on every aspect of Libya's geology. The three volumes of this major treatise provide just that, including in their scope stratigraphy and biostratigraphy, palaeontology, sedimentation, hydrology and hydrogeology, Quaternary geology and geomorphology, petroleum geology, mineralogy and economic geology, igneous petrology, structural geology and geophysics.

\section{Gravity,Deformation and the Earth's Crust}

\section{Second Edition}

Hans Ramberg

June 1981, xii + 452pp., £32.80 (UK only) / \$79.00, 0.12.576860.5

The first edition of Gravity, Deformity and the Earth's Crust made an extremely important contribution to the geological sciences by illustrating how problems in geodynamics and tectonics can be illuminated by the use of experimental scale models combined with theoretical mechanics analysis. In the second edition this approach has been extended, on the one hand to include new details and analysis of structures described in the first edition, and on the other to encompass further geological problems which have arisen since the first publication.

\section{Academic Press}

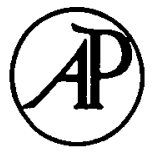

A Subsidiary of Harcourt Brace Jovaniovich, Publishers London New York Toronto Sydney San Francisco 24-28 Oval Road, London NW1 7DX, England 111 Fifth Avenue, New York, NY 10003, USA 
Contributions for publication should be addressed to The Editors, Geological Magazine, Department of Earth Sciences, Downing Street, Cambridge CB2 3EQ, England.

All contributions, whether articles, correspondence or reviews, must be typed in duplicate on one side of the paper, double spaced throughout, with a wide margin on the left of each page and a narrower margin on the right. Any minor corrections should be made neatly in the typescript, leaving the margins clear.

The total length of a paper should not in general exeeed 20 pages of the Geological Magazine; preference and priority are given to short papers. Longer papers (between 20 and 40 pages of Geological Magazine) will from time to time be considered, but authors wishing to submit such manuscripts should first request further details.

The accuracy of references is the responsibility of authors. References must be double spaced and abbreviated in the form of the World List of Scientific Periodicals 4th Edition as far as possible, e.g.

Brooks, M. \& James, D. G. 1975. The geological results of seismic refraction surveys in the Bristol Channel, 1970-73. Q. Jl geol. Soc. Lond. 131, 163-82.

Kirby, G. A. 1978. Layered gabbros in the Eastern Lizard, Cornwall, and their significance. Geol. Mag. 115, 199-204.

Books should be cited as:

Ramsey, J. G. 1967. Folding and Fracturing of Rocks. New York: McGraw-Hill.

Bott, M. H. P. 1973 The evolution of the Atlantic north of the Faroe Islands. In Implications of Continental Drift to the Earth Sciences, vol. 1 (ed. D. H. Tarling and S. N. Runcorn), pp. 175-89. London, New York: Academic Press.

Unpublished work, e.g. from theses, should normally be referred to in the text in parentheses and not included in the reference list unless in the press.

Articles must be accompanied by a brief summary. Contributions should follow the general style of papers in recent issues of the Magazine and the principles laid down in Notes to Authors (Proc. Geol. Soc. Lond., No. 1627. Oct. 1965). Headings should be set out clearly, but not underlined. Primary headings should be in lower case, at margin, with arabic numeral; sub-headings should be numbered 2.a, 2.b, etc., and tertiary headings 2.a.1., 2.a.2. No cross-references should be given by page number, but 'above' and 'below' should be used with the section specified, e.g. Section 2.a.1.

Illustrations must be drawn to allow reduction to maximum size of $200 \mathrm{~mm} \times$ $134 \mathrm{~mm}$; originals should normally be drawn at twice final size and must be sent in a flat package. Lettering must allow for legibility after reduction (i.e. equivalent to $1 \mathrm{~mm}$ as a minimum on reduction). Duplicates of illustrations may be prints or, preferably, reductions. Metric units of the SI system are preferred. Illustrations in the text will be referred to as figures (Fig. 2, 2a, etc.), and halftone plates will be referred to (also in arabic) as Plates 2, $2 a$, etc. Folding plates will not be accepted. Captions for figures and plates must be typed on separate sheets.

Twenty-five offprints of each paper will be provided free of charge. Additional offprints may be purchased according to a set scale of charges. 


\section{Geological Magazine}

\section{Volume 118, Number 5, September 1981}

ROCK, N. M. S.

How should igneous rocks be grouped?

$449-461$

HOARE, P. G. \& CONNELL, E. R.

The chalky till at Barrington, near Cambridge, and its connection with other

$463-476$

Quaternary deposits in southern Cambridgeshire and adjoining areas

LAMBERT, R. ST J., WINCHESTER, J. A. \& HOLLAND, J. G.

Comparative geochemistry of pelites from the Moinian and Appin Group (Dalradian)

$477-490$

of Scotland

ROTHSTEIN, A. T. V.

The primary crescumulates of the Lizard peridotite, Cornwall

$49^{1-500}$

JOHNSON, M. R. W.

The erosion factor in the emplacement of the Keystone thrust sheet (South East

$501-507$

Nevada) across a land surface

BANHAM, P. H., HOPPER, F. M. W. \& JACKSON, J. B.

The Gillbrea Nappe in the Skiddaw Group, Cockermouth, Cumbria, England

EVANS, K. M.

A marine fauna from the Dartmouth Beds (Lower Devonian) of Cornwall

$509-516$

$5^{17-523}$

MASON, R.

A trondhjemite vein in the Sulitjelma Gabbro, Norway, and its implications for the age of the Sulitjelma Ophiolite

HANCOCK, P. L., AL-KHATIEB, S. O. \& AL-KADHI, A.

Structural and photogeological evidence for the boundaries to an East Arabian block

PICCARRETA, G.

Deep-rooted overthrusting and blueschistic metamorphism in compressive continental margins. An example from Calabria (Southern Italy)

SOLIMAN, M. M.

Geochemical surveys for $\mathrm{Sn}, \mathrm{Nb}, \mathrm{Cu}$ and Au mineralization, Mueilha-Dungash area, Southeastern Desert, Egypt

BENTON, M. J. \& WALKER, A. D.

The use of flexible synthetic rubbers for casts of complex fossils from natural moulds

GALE, A. S. \& WOODROOF, P. B.

A Coniacian ammonite from the 'Top Rock' in the Chalk of Kent

$525^{-531}$

$533^{-}-53^{8}$

$539-544$

$545-549$

$55^{1-556}$

$557-560$

CORRESPONDENCE

A new occurrence of possible Tertiary deposits in south-western Dyfed: P. M. ALLEN

The neotype of Retepora nodulosa Phillips, 1836: R,TAVENER-SMITH

The base of the Ludlow Series in the graptolitic facies: D. E. WHITE

$5^{61-564}$

565

566

ESSAY REVIEW

W. B. HARLAND

Introducing New Zealand Geology

REVIEWS

PUBLICATIONS RECEIVED

(C) Cambridge University Press 1981

Printed in Great Britain at the University Press, Cambridge 